\title{
透明 $\mathrm{Y}_{2} \mathrm{O}_{3}$ の焼結に及ぼす $\mathrm{BeO}$ の影響*
}

\author{
戸田堯 三**，松山㛜**
}

\begin{abstract}
Gyozo Toda and Iwao Matsuyama: Effect of $\mathrm{BeO}$ Addition on Sintering of Transparent $\mathrm{Y}_{2} \mathrm{O}_{3}$.

The effects of $\mathrm{BeO}$ addition $(0 \sim 2 \mathrm{wt} \%)$ on the pressureless sintering process and the transparency of yttria were studied. The addition of $\mathrm{BeO}(0.1 \sim 0.5 \mathrm{wt} \%)$ promoted the sintering of $\mathrm{Y}_{2} \mathrm{O}_{3}$ to decrease markedly the residual pores in sintered bodies above $2100^{\circ} \mathrm{C}$. The transparency of sintered $\mathrm{Y}_{2} \mathrm{O}_{3}$ was independent of compacting pressure $\left(1 \sim 10 \mathrm{t} / \mathrm{cm}^{2}\right)$. BeO vaporized with the increase of sintering temperature and more than half of the initial contents of $\mathrm{BeO}$ decreased above $1800^{\circ} \mathrm{C}$. The transmittance (thickness $1.0 \mathrm{~mm}$, wave length $300 \sim 7000 \mathrm{~nm}$ ) of the $0.1 \mathrm{wt} \% \mathrm{BeO}-\mathrm{Y}_{2} \mathrm{O}_{3}$ sintered at $2150 \sim 2250^{\circ} \mathrm{C}$ for $50 \sim$ $300 \mathrm{~min}$. in $\mathrm{H}_{2}$ was $80 \%$. It was suggested that the liquid phase formation of $\mathrm{Y}_{2} \mathrm{O}_{3}-\mathrm{BeO}$ system and the vaporization of $\mathrm{BeO}$ contributed to the fabricating of the transparent $\mathrm{Y}_{2} \mathrm{O}_{3}$. (Received June 22, 1987)
\end{abstract}

\section{I 緒 言}

$\mathrm{Y}_{2} \mathrm{O}_{3}$ は立方晶の結晶構造1 を皇つために光透過率が 高く ${ }^{2}$ ，耐熱性に富み， $\mathrm{Na}$ 亿対する耐食性に優れてい

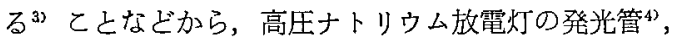
あるいは耐熱性光透過空材25 として有望視されている。

透明 $\mathrm{Y}_{2} \mathrm{O}_{3}$ の焼結に関するてれまでの報告は，ホット プレス法と常圧焼結法とに分けられる. Brissette ら5) は, $\mathrm{Y}_{2} \mathrm{O}_{3}$ 粉末を $1000 \sim 1500^{\circ} \mathrm{C}$, 約 $35 \sim 70 \mathrm{MPa}$ の条件 で Hot-Forging する方法で，維密な $\mathrm{Y}_{2} \mathrm{O}_{3}$ 鈤結体を得， Lefever ら²) は, 3〜 5wt\% $\%$ LiF を添加した $\mathrm{Y}_{2} \mathrm{O}_{3}$ 粉末成 形体を真空中でホットプレスし，光透過滀80\%以上（試 料厚さ $1.0 \mathrm{~mm}$, 波長 $1.5 \sim 6 \mu \mathrm{m}$ ) の焼結体を得ている. またDutta ら ${ }^{6)}$ は, 純 $\mathrm{Y}_{2} \mathrm{O}_{3}$ 粉末の真空ホットプレス 法により，上記同様の透明体の得られることを報告して いる。

常圧焼結法としては, $\mathrm{Y}_{2} \mathrm{O}_{3} に 10 \mathrm{~mol} \% \mathrm{ThO}_{2}$ を添加 して透明化焼結する方法 ${ }^{7)}$, 純 $\mathrm{Y}_{2} \mathrm{O}_{3}$ 粉を高圧 $\left(10 \mathrm{t} / \mathrm{cm}^{2}\right)$ 成形後に焼結する方法 ${ }^{8}$, 及び出発原料として $\mathrm{Y}_{2}\left(\mathrm{CO}_{3}\right)_{3}$, あるいは $\mathrm{Y}_{2}\left(\mathrm{C}_{2} \mathrm{O}_{4}\right)_{3}$ を用い，これに 0.05〜0.25 wt\% の $\mathrm{Al}_{2} \mathrm{O}_{3}$ ，あるいは 8〜 $11 \mathrm{~mol} \%$ の $\mathrm{La}_{2} \mathrm{O}_{3}$ を添加して焼結 する方法9,10) が報告されている。

これらの従来報告を, 放電灯用発光管への応用という 立場から見ると，ホットプレス法や高圧で成形体を作る 方法は管状の焼結体を作製する方法として適当ではなく， また出発原料䎲イットリウム塩類を用いる方法は，原料 費や工数増加などに難点があると思われる.

$\mathrm{Y}_{2} \mathrm{O}_{3}$ をほぼ理論密度にまでち密化するためには，そ
の融点 $\left(2433 \sim 2440^{\circ} \mathrm{C}\right)^{11,122}$ 近くまで加熱しなければな らない。しかし, $\mathrm{Y}_{2} \mathrm{O}_{3}$ は $2270^{\circ} \mathrm{C}$ K Cubic $\rightarrow$ Hexagonal 相変態" があり，との変態点通過の時の体積变化偟よっ て焼結体にクラックを生ずる7,137. したがって，クラッ クの発生がなく，かつ常圧焼結によって $\mathrm{Y}_{2} \mathrm{O}_{3}$ を透明化 するには焼結助剂の使用が勃果的であると考えられる. ところか焼結体中に焼結助版が残留すると，乙れが光散 乱中心となって光透過率低下の原因となる。

以上の観点から, 本報告は烧結温度付近での蒸気压の 高い $\mathrm{BeO}$ を焼結助剂として取り上げ， $\mathrm{Y}_{2} \mathrm{O}_{3}$ の透明化 焼結に及ぼすその影響について検討したあのである。

\section{II 試料及び実験方法}

\section{凸-1 試料}

用いた $\mathrm{Y}_{2} \mathrm{O}_{3}$ 粉末（信越化学製）の營光X楾法に上る 分析結果を Table 1 亿, 粒度分布 (日立 PSA-2 型粒度 分布測定装置）を Fig. 1 に示す. 光吸収の原因となる $\mathrm{Fe}, \mathrm{Cu}$ などの不純物含有量証非常に少なく, 平均粒子 径は約 $5 \mu \mathrm{m}$ である. 㜔結助剂である $\mathrm{BeO}$ は, $\mathrm{BeSO}_{4}$. $4 \mathrm{H}_{2} \mathrm{O}$ を出発原料として用いた。，その分光分析結果を Table 2 亿示す.

$\mathrm{BeSO}_{4} \cdot 4 \mathrm{H}_{2} \mathrm{O}$ の水溶液の所定量を $\mathrm{Y}_{2} \mathrm{O}_{3}$ 粉末儿加元,

Table 1 Impurities of raw $\mathrm{Y}_{2} \mathrm{O}_{3}$ powder (ppm).

\begin{tabular}{c|c|c|c}
\hline $\mathrm{Fe}$ & $\mathrm{Cu}$ & $\mathrm{Dy}_{2} \mathrm{O}_{3}$ & $\mathrm{~Tb}_{4} \mathrm{O}_{7}$ \\
\hline 3 & 0.2 & 320 & $<30$ \\
\hline
\end{tabular}

昭和 62 年 6 月 22 日受理.

**（株）日立製作所中央研究所, 下185国分寺市東恋ヶ寉1-280. 


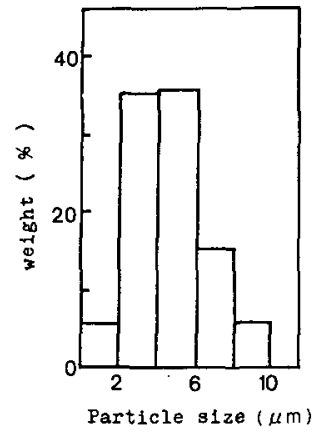

Fig. 1 Particle size distribution of $\mathrm{Y}_{2} \mathrm{O}_{3}$.

Table 2 Impurities of $\mathrm{BeSO}_{4}-4 \mathrm{H}_{2} \mathrm{O}$ (ppm).

\begin{tabular}{c|c|c|c|c}
\hline $\mathrm{Si}, \mathrm{Fe}$ & $\mathrm{P}$ & $\mathrm{Cu}$ & $\mathrm{Al}, \mathrm{B}, \mathrm{Mn}, \mathrm{Zn}$ & $\mathrm{Ca}, \mathrm{Mg}, \mathrm{Na}$ \\
\hline $50 \sim 100$ & $<100$ & $5 \sim 10$ & 10 & $<5$ \\
\hline
\end{tabular}

十分混合後，㩇拌しなが弓乾燥して種々の Be 含有量の 湿合粉末を作った. この混合粉末を $10 \times 30 \times 2.0 \mathrm{~mm}$ の 大きさに $1 \sim 10 \mathrm{t} / \mathrm{cm}^{2} \quad(980 \sim 9800 \mathrm{MPa})$ の圧で成形 し，さらに空気中， $850^{\circ} \mathrm{C}, 1 \mathrm{hr}$ 加熱するととにより， $\mathrm{Be}$ 硫酸塭を $\mathrm{BeO}$ 亿変化させた.

焼結は，Fig. 2 亿示すように W 発熱体上Mo 反射板 と加ら構成される電気炉を用い, 純化水素 (露点 $-36^{\circ} \mathrm{C}$ ) 中で行った。昇温速度は， $1200^{\circ} \mathrm{C}$ までは約 $30 \mathrm{~min}$, $1200^{\circ} \mathrm{C}$ 以上では $1000^{\circ} \mathrm{C} / 30 \mathrm{~min}$ とし, 所定温度に所定 時間保持後, $10 \mathrm{~min}$ で $1800^{\circ} \mathrm{C}$ 亿降温し, 雾囲気水素の 露点を室温に切り換えてての温度に $20 \mathrm{~min}$ 保持し，そ の後 $40 \mathrm{~min}$ で室温まで冷却した. $1800^{\circ} \mathrm{C}$ で簬点を变え たのは黒化した $\mathrm{Y}_{2} \mathrm{O}_{3}$ 學結体”を脱色するためである.

焼結した試料を所定の厚さに研摩後, ダイヤモンドペ 一ストで仕上げて，光学顕微鏡観察及び光透過率測定試 料とした。

\section{II - 2 実験方法}

收縮率：Fig. 2 の電気炉の上部反射板を取り除き, 発 就体中央部に $\mathrm{Y}_{2} \mathrm{O}_{3}$ 成形体を水平汇設置し，のぞき空を 通して蒜取顕微鏡 (5/100 mm 目盛付)により，加熱に よる試料の寸法变化至測定し，次式により線仪縮率 $(1 \%)$

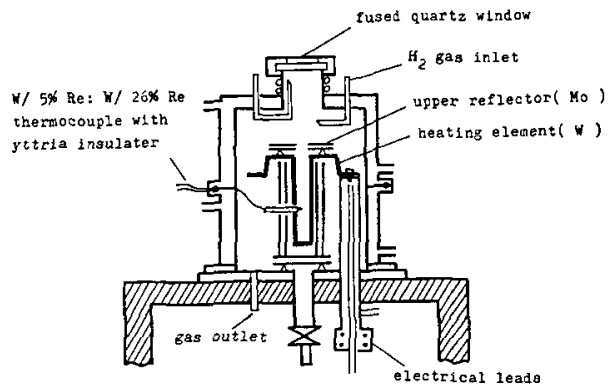

Fig. 2 Sintering furnace for $\mathrm{Y}_{2} \mathrm{O}_{3}$.
定求めた。

$$
1 \%=\left[\left(l_{0}-l_{\mathrm{T}}\right) / l_{0}\right] \times 100
$$

$\left(l_{0}:\right.$ 成形体の長さ, $l_{\mathrm{T}}: \mathrm{T}^{\circ} \mathrm{C}$ での長さ)

光透過率：鏡面研摩した試料（厚さ $1.0 \mathrm{~mm}$ ) 亿つき， 分光光電光度計 (日立 EPU-2A 形, 340 形, 260-1 形) を用いて测定した ${ }^{(4)}$.

気孔，結晶粒径：気孔は鏡面仕上げした試料面につき， 光学顕微鏡により観察した. 結晶粒径は，試料面を $\mathrm{HCl}$ : $\mathrm{H}_{2} \mathrm{O}(1: 1)$ 混液で腐食し，横断法により求めた。

\section{III 実 験 結 果}

\section{III -1 狫結収縮曲線}

Fig. 3 K，純 $\mathrm{Y}_{2} \mathrm{O}_{3}$ (成形圧力 $5 \mathrm{t} / \mathrm{cm}^{2}$ ) 及び $0.1 \mathrm{wt} \%$ $\mathrm{BeO}$ 添加 $\mathrm{Y}_{2} \mathrm{O}_{3}\left(3 \mathrm{t} / \mathrm{cm}^{2}\right)$ 成形体の加熱収縮曲線を示す.

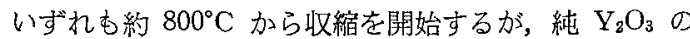
場合, 約 $2000^{\circ} \mathrm{C}$ まで連続的に収縮が進行する. これに 対し $\mathrm{BeO}$ 添加武料は, $1600^{\circ} \mathrm{C}$ まで急激仁収縮した後, それ以上の温度での収縮はゆるやかであり，両者を比較 すると $800 \sim 1600^{\circ} \mathrm{C}$ 間で， $\mathrm{BeO}$ 添加によって $\mathrm{Y}_{2} \mathrm{O}_{3}$ の 占密化が促進されることか浔められる。

なお，Fig. 3 において，収縮率測定後の試料密度は約 $5.0 \mathrm{~g} / \mathrm{cm}^{3}$ で両者共にほぼ等しい值を示したが，2000 $\mathrm{C}$ 以上での収縮率に差があるのは耐者の成形生力が異なる ためである。

III-2 光透過率に及ぼす $\mathrm{BeO}$ 添加量及び成形俚力の影 響

$\mathrm{BeO}$ 添加量を变えた $\mathrm{Y}_{2} \mathrm{O}_{3}$ 成形体 (成形圧力 $2 \mathrm{t} / \mathrm{cm}^{2}$ ) を， $2250^{\circ} \mathrm{C}, 300 \mathrm{~min}$ 焼結した之きの焼結体の光透過率 を Fig.4 に示す。ここには示していないか， $\mathrm{BeO}$ 無添

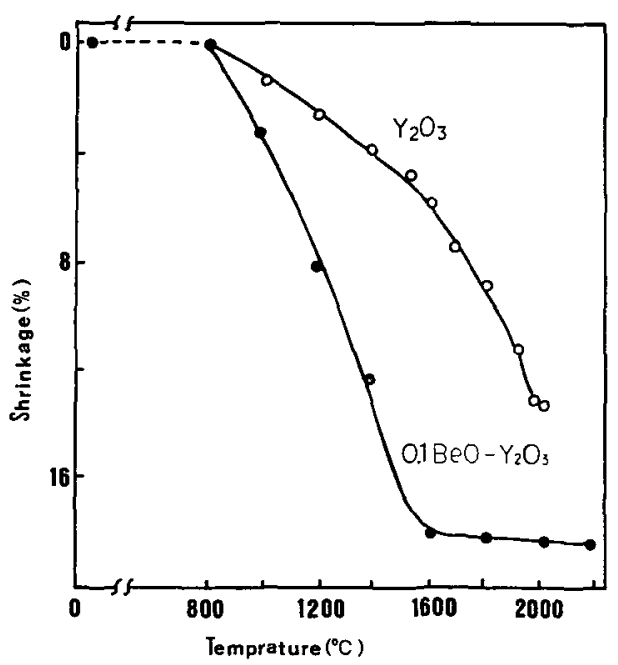

Fig. 3 Linear shrinkage curves of $\mathrm{Y}_{2} \mathrm{O}_{3}$ and $0.1 \mathrm{wt} \%$ $\mathrm{BeO}-\mathrm{Y}_{2} \mathrm{O}_{3}$ compacted at $5 \mathrm{t} / \mathrm{cm}^{2}$ and $3 \mathrm{t} / \mathrm{cm}^{2}$, respectively. 


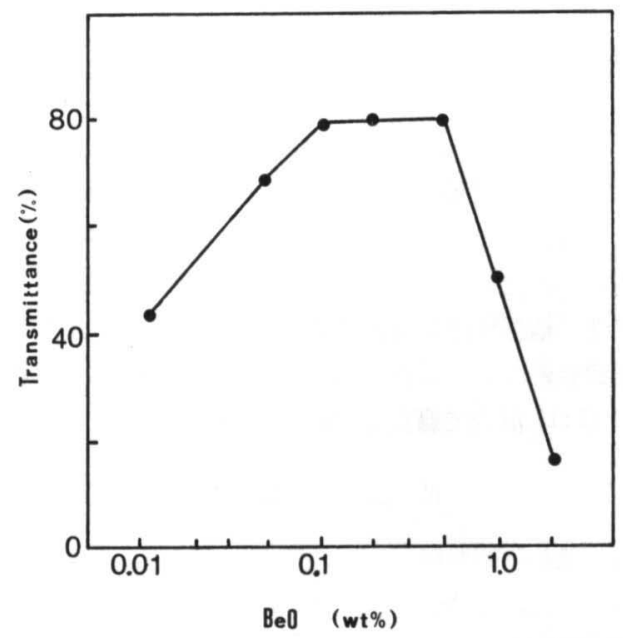

Fig. 4 Relationship between $\mathrm{BeO}$ content and the transmittance of $\mathrm{Y}_{2} \mathrm{O}_{3}$ sintered at $2250^{\circ} \mathrm{C}$ for $300 \mathrm{~min}$.

加 $\mathrm{Y}_{2} \mathrm{O}_{3}$ の光透過率が約 $30 \%$ あ゙あので, $\mathrm{BeO}$ 添加効 果の非常に大きいととが分かる. $\mathrm{BeO}$ 添加量が増すにつ れて光透過率は増加し， $0.1 \mathrm{wt} \% \mathrm{BeO}$ でほぼ飽和後, $0.5 \mathrm{wt} \% \mathrm{BeO}$ 以上の添加では急激に隇少する. したがっ て, 高い光透過率を得るために必要な $\mathrm{BeO}$ 添加量は $0.1 \sim 0.5 \mathrm{wt} \%$ となる. なお, $2 \mathrm{wt} \% \mathrm{BeO}$ 試料では半溶 融状態が見られた.

つぎに, $0.1 \mathrm{wt} \% \mathrm{BeO}$ 添加 $\mathrm{Y}_{2} \mathrm{O}_{3}$ の成形圧力と透光性 の関係を Photo. $1\left(2150^{\circ} \mathrm{C}, 60 \mathrm{~min}\right.$ 焼結) に示す. $\mathrm{Y}_{2} \mathrm{O}_{3}$ 粉末は非常に成形性に富み, 有機バインダーを添加せず に $10 \mathrm{t} / \mathrm{cm}^{2}$ の圧力で成形してあ成形体にクラックは発 生しない. Photo. 1 上り, 光透過率の成形圧力依存性は 認められず, $2250^{\circ} \mathrm{C}, 300 \mathrm{~min}$ 燒結の場合あ 1 10 t/ $/ \mathrm{cm}^{2}$ の圧力範囲で光透過率70 80\%の值を示した． 純 $\mathrm{Y}_{2} \mathrm{O}_{3}$ では高い光透過率を得るために $10 \mathrm{t} / \mathrm{cm}^{2}$ の成形圧力が 必要とされる ${ }^{15)}$ が, $\mathrm{BeO}$ を添加すればこのような高い 圧力を用いずに高透光性の焼結体が得られる.

III-3 焼結温度, 時間の影響

Fig. 5 亿, 0.1wt\% BeO 添加 $\mathrm{Y}_{2} \mathrm{O}_{3}$ (成形圧力 $2 \mathrm{t} / \mathrm{cm}^{2}$ ) を種々の温度で $300 \mathrm{~min}$ 焼結したときの光透過率 (試料

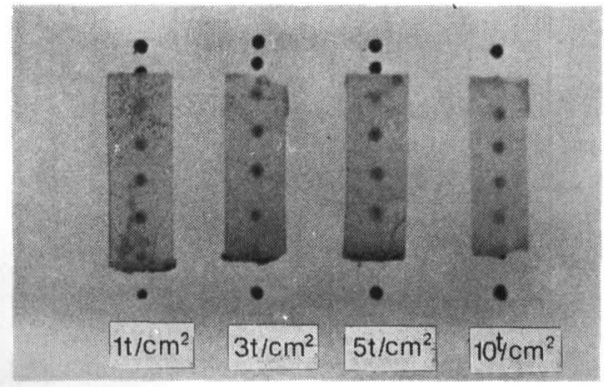

Photo. 1 Effect of compacting pressure on the transparency of $0.1 \mathrm{wt} \% \mathrm{BeO}-\mathrm{Y}_{2} \mathrm{O}_{3}$ sintered at $2150^{\circ} \mathrm{C}$ for $60 \mathrm{~min}$ (as sintered).

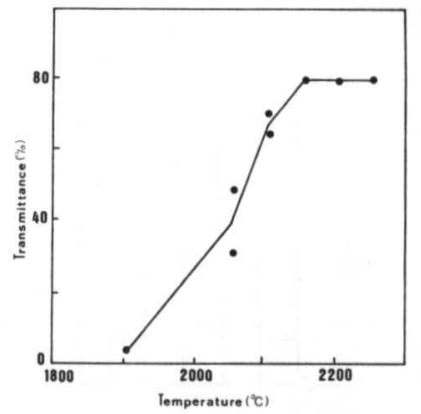

Fig. 5 Effect of sintering temperature on the transmittance of 0.1 wt $\% 6 \mathrm{BeO}-\mathrm{Y}_{2} \mathrm{O}_{3}$ (time: $300 \mathrm{~min}$ ).

厚さ $1.0 \mathrm{~mm})$ の変化を示す. 温度の上昇と共に光透過 率は増加し, $2150^{\circ} \mathrm{C}$ 以上で一定となる. 純 $\mathrm{Y}_{2} \mathrm{O}_{3}$ の場 合, 光透過率 $80 \%$ を得るには $2270^{\circ} \mathrm{C}$ で焼結する必要が ある (試料厚さ $0.76 \mathrm{~mm}$ ) と報告されている ${ }^{15)}$ が, $\mathrm{BeO}$ 添加すれば燒結温度をとれよりも約 $100^{\circ} \mathrm{C}$ 低くすると とができる。

なお，焼結温度が $2300^{\circ} \mathrm{C}$ になると燒結体に多数のク ラックか認められたが，乙れは前述のように $\mathrm{Y}_{2} \mathrm{O}_{3}$ の変 態点 $\left(2270^{\circ} \mathrm{C}\right)^{12}$ 通過による体積変化汇起因するものと思 われる. また, Fig. 5 の試料の粒成長は焼結温度にほほ 比例していたが, $2150 \sim 2250^{\circ} \mathrm{C}$ で 300 900 $\mu \mathrm{m}$ と著し く粗大化しており，他の透明セラミックス ${ }^{14)}$ の場合と 大きく異なっていた.

Photo. 2 は焼結温度による気孔の変化を, 純 $\mathrm{Y}_{2} \mathrm{O}_{3}$ と $0.1 \mathrm{wt} \% \mathrm{BeO}$ 添加 $\mathrm{Y}_{2} \mathrm{O}_{3}$ について比較した結果である. $2000^{\circ} \mathrm{C}$ では両者の気孔量に余り差はないが, $2100^{\circ} \mathrm{C}$ 以 上で $\mathrm{BeO}$ 添加試料の気孔が激減し，てれが Fig. 4 の光 透過率の増加に大きく寄与していると考えられる.

つぎに, 焼結温度を $2150,2250^{\circ} \mathrm{C}$ として, 焼結時間 による光透過率の変化を Fig. 6 亿示す. $70 \%$ 以上の高い 光透過率を得るには, $2150^{\circ} \mathrm{C}$ で $300 \mathrm{~min}, 2250^{\circ} \mathrm{C}$ では $50 \mathrm{~min}$ 以上の焼結が必要なととが分かる. Fig.7 は, $2250^{\circ} \mathrm{C}, 300 \mathrm{~min}$ の条件で焼結した $0.1 \mathrm{wt} \% \mathrm{BeO}-\mathrm{Y}_{2} \mathrm{O}_{3}$ 焼結体 (厚さ $1.0 \mathrm{~mm}$ ) の光透過率の波長依存性を示した あので, 紫外吸収端 $220 \mathrm{~mm}$, 赤外吸収端 $11000 \mathrm{~nm}$, 波長 300 7000 nm での光透過率が80\%で，単結晶 $\mathrm{Y}_{2} \mathrm{O}_{3}{ }^{2)}$ の值と同等である.

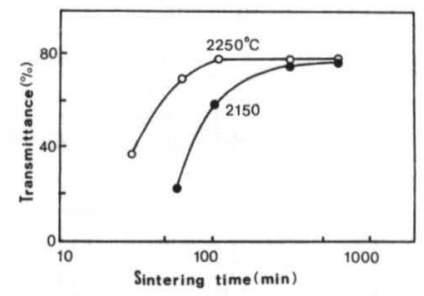

Fig. 6 Sintering time dependence of the transmittance of $0.1 \mathrm{wt} \% \mathrm{BeO}-\mathrm{Y}_{2} \mathrm{O}_{3}$ sintered at each temperature. 

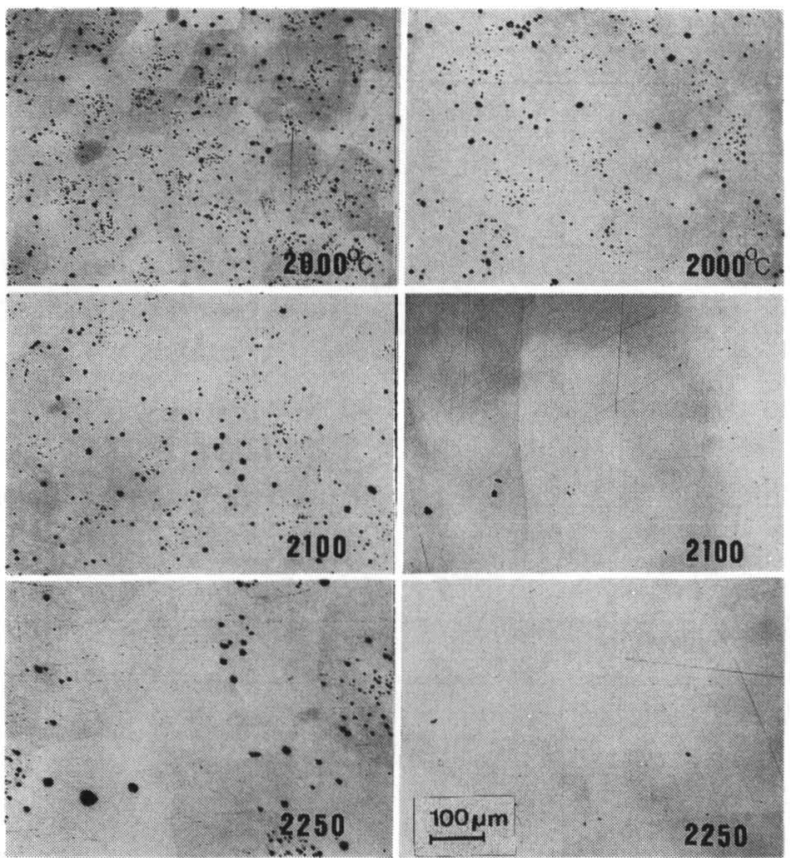

Photo. 2 Pore photographs of (A) $\mathrm{Y}_{2} \mathrm{O}_{3}$ and (B) $0.1 \mathrm{wt} \% \mathrm{BeO}-\mathrm{Y}_{2} \mathrm{O}_{3}$ sintered at various temperature.

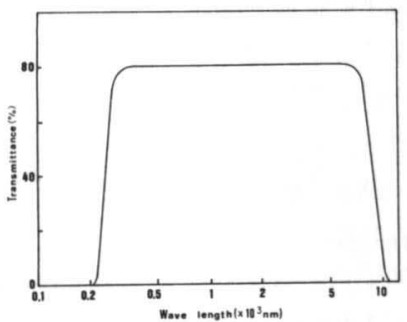

Fig. 7 Transmission spectra of $0.1 \mathrm{wt} \% 6 \mathrm{BeO}-\mathrm{Y}_{2} \mathrm{O}_{3}$ sintered at $2250^{\circ} \mathrm{C}$ for $300 \mathrm{~min}$.

III-4 $\mathrm{Y}_{2} \mathrm{O}_{3}$ 中の $\mathrm{BeO}$

Table 3 は, $\mathrm{BeO}$ 添加量を変えて作製した $\mathrm{Y}_{2} \mathrm{O}_{3}$ 成形 体を, $2250^{\circ} \mathrm{C}, 60 \mathrm{~min}$ の条件で焼結したときの焼結体中 の $\mathrm{BeO}$ 含有量を示したもので, 分光分析による $\mathrm{Be}$ 分 析值を $\mathrm{BeO}$ に換算して表してある. $\mathrm{BeO}$ 添加量が増す につれて焼結体中に残留する $\mathrm{BeO}$ 量む多くなるが, 総 じて焼結体中の $\mathrm{BeO}$ 量は添加量の $1 / 10$ 程度に減少して

Table 3 Change in $\mathrm{BeO}$ content of $\mathrm{Y}_{2} \mathrm{O}_{3}$ containing $0-1.0 \mathrm{wt} \% \mathrm{BeO}$ sintered at $2250^{\circ} \mathrm{C}$ for $1 \mathrm{hr}$ (wt \%).

\begin{tabular}{c|l}
\hline Doped BeO & Sintered body \\
\hline 0 & $0.0001-0.0003$ \\
0.001 & $0.0003-0.001$ \\
0.005 & $0.0003-0.001$ \\
0.01 & $0.0003-0.01$ \\
0.1 & $0.003-0.01$ \\
0.5 & $0.01-0.03$ \\
1.0 & $0.01-0.03$ \\
\hline
\end{tabular}

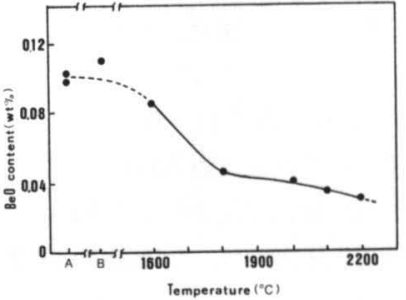

Fig. 8 Variation of amount of $\mathrm{BeO}$ with sintering temperature of 0.1 wt $\% \mathrm{BeO}-\mathrm{Y}_{2} \mathrm{O}_{3}$ sintered in dry $\mathrm{H}_{2}$ for $60 \mathrm{~min}$.

いる. これは, $\mathrm{BeO}$ の蒸気圧が $2200^{\circ} \mathrm{C}$ で $10^{-2}$ torr $^{16)}$ と高いために, 焼結過程で揮散したためと考えられる.

Fig. 8 に, 0.1wt\% $\mathrm{BeO}$ 添加 $\mathrm{Y}_{2} \mathrm{O}_{3}$ を種々の温度に加 熱 $\left(\mathrm{H}_{2}\right.$ 露点 $-36^{\circ} \mathrm{C}$, 各温度 $60 \mathrm{~min}$ 保持) した後の, 焼結体中の $\mathrm{BeO}$ 残留量を無機定量法により分析した結 果を示す. $850^{\circ} \mathrm{C}$ 処理試料中の $\mathrm{BeO}$ 量が混合粉のそれ よりやや多いのは分析誤差と思われるが, $1600^{\circ} \mathrm{C}$ です でに $\mathrm{BeO}$ の揮散が起こり, $1800^{\circ} \mathrm{C}$ では添加量の $1 / 2$ 以 下となり，さらに温度の上昇と共に漸減する.

\section{IV 結 果の 検 討}

$\mathrm{Y}_{2} \mathrm{O}_{3}-\mathrm{BeO}$ 系の共晶点 $(65 \mathrm{~mol} \% \mathrm{BeO})$ は $1580^{17)} \sim$ $1595^{\circ} \mathrm{C}^{18)}$ であるので, この系の焼結過程では液相の発 生が予想される. しかし, Fig. 3 に示した約 $1600^{\circ} \mathrm{C}$ 以 下の低い温度領域での $\mathrm{Y}_{2} \mathrm{O}_{3}$ と $\mathrm{BeO}$ 添加試料との収縮 曲線の相違に対しては, 上記液相が関与しているとは考 え難い. また, $\mathrm{BeO}$ 原料中の不純物である $\mathrm{Si}$ や $\mathrm{P}$ 
(Table 2) と $\mathrm{Y}_{2} \mathrm{O}_{3}$ との反忘による液相の生成も，乙れ らの量が極めて少ないため，本実験ではその影響を無視 できるであろうと思われる.

$\mathrm{Al}_{2} \mathrm{O}_{3}$ の固相焼結では，微量の $\mathrm{TiO}_{2}$ 添加肪ち密化を 促進するととが知られている格 ${ }^{121}$. 浜野ら ${ }^{201}$ は, $\alpha-\mathrm{Al}_{2} \mathrm{O}_{3}$ に $0.2 \mathrm{wt} \%$ 程度の $\mathrm{TiO}_{2}$ 专添加した場合, $1300 \sim 1500^{\circ} \mathrm{C}$ の比較的低い焼結温度でち密な洷結体が得られ，乙れは $\mathrm{Al}_{2} \mathrm{O}_{3}$ 中への $\mathrm{TiO}_{2}$ の固溶によって焼結が促進されたも のよ考えている.

$\mathrm{BeO}$ 添加 $\mathrm{Y}_{2} \mathrm{O}_{3}$ の場合, 共晶温度での $\mathrm{Y}_{2} \mathrm{O}_{3}$ に対する $\mathrm{BeO}$ の固溶量 ${ }^{18)}$ が $0.5 \mathrm{wt} \%$ (約 $5 \mathrm{~mol} \%$ ) 程度上見積 られるので, 前述の $\mathrm{Al}_{2} \mathrm{O}_{3}$ の例之同様, $\mathrm{Y}_{2} \mathrm{O}_{3}$ 中への $\mathrm{BeO}$ の固溶か $\mathrm{Y}_{2} \mathrm{O}_{3}$ の䡒結促進に奇与していると推定 される. しかし, 純 $\mathrm{Y}_{2} \mathrm{O}_{3}$ 及び 0.1wt $\%$ BeO 添加 $\mathrm{Y}_{2} \mathrm{O}_{3}$ 試料 $\left(2200^{\circ} \mathrm{C}, 60 \mathrm{~min}\right.$ 焼結) をX線回折により格子定数 を比較した結果では, 両者の差が検出されず, $\mathrm{Y}_{2} \mathrm{O}_{3}$ 中 への $\mathrm{BeO}$ の固溶を確認することができなかった。

$\mathrm{Y}_{2} \mathrm{O}_{3}$ が高透光性を示すためには，光の吸収原因とな る不純物, 及び光散乱中心となる気孔や異相ができるだ け少ないととが必要である. 本研究では高純度の原料を 用い，雾囲気污染の少ない焼結炉を用いているので不純 物による影響を無視し，また， $\mathrm{Y}_{2} \mathrm{O}_{3}$ は立方晶であるか ら光学異方性に起因する光散乱か非常に小さいととなど を考元ると， $\mathrm{Y}_{2} \mathrm{O}_{3}$ の透光性を支配する因子は，残留気 孔之添加物による異相上に限られる. 通常, 与密化過程 は気孔率や密度の変化で表されることが多いが, 焼結体 が理論密度に近い場合には, 光透過率がち密化の尺度と して適している(4).

Fig. 3 に㧍ける $1600^{\circ} \mathrm{C}$ 以上での $\mathrm{BeO}$ 添加試料の収 縮はゆるやかであるが， Fig. 5 の光透過率は 1800〜 $2150^{\circ} \mathrm{C}$ 間であ著しく增加しており，また気孔は $2150^{\circ} \mathrm{C}$ 以上で激减している (Photo.2). 前述のように, $\mathrm{Y}_{2} \mathrm{O}_{3}$ $\mathrm{BeO}$ 系は約 $1600^{\circ} \mathrm{C}$ 亿共晶点があるため, 焼結温度が これより高くなると， $\mathrm{Y}_{2} \mathrm{O}_{3}$ と $\mathrm{BeO}$ の反応によって $\mathrm{Y}_{2} \mathrm{O}_{3}$ 粒子の表面近傍に液相膜が形成される可能性があ り、てれが $1600^{\circ} \mathrm{C}$ 以上でのち密化に寄与していると思 わ机る. 高透光性走示すために必要な $\mathrm{BeO}$ 添加量 $(0.1$ 〜 0.5wt\%) は，共晶組成の $\mathrm{BeO}$ 量 (17wt\%)よりあか なり少ないが， $\mathrm{Y}_{2} \mathrm{O}_{3}$ 粒子表面では $\mathrm{BeO}$ が高濃度にな っているとと, 及び $2 \mathrm{wt} \% \mathrm{BeO}$ 添加試料が $2250^{\circ} \mathrm{C}$ で 半溶融状態を示したことなどから, $\mathrm{BeO}$ 添加量が少ない 場合であって屯，液相形成のあるととか推測される。

一般に，液相焼結によって固体がち密化するためには， 十分な量の液相が必要とされているが21 , 本実験で発生 する液相量は $\mathrm{BeO}$ 添加量に対応して非常に少ないであ ろうと思われる。微量の焼結助剤が母相粒子と反応して 液相を生じ，それがち密化を著しく促進させたり，焼 結開始温度を低下させたりすることが， $\mathrm{SiO}_{2}$ 添加の
$\mathrm{SrFe}_{12} \mathrm{O}_{17}{ }^{22}$ や, $\mathrm{CaO}$ 添加 $\mathrm{AlN}^{23)}$ などで知られている. これらの場合も液相量は非常に少なく, ち密化を支配す るのは液相中への固体粒子の溶解, 析出であると考えら れている.

焼結体の結晶粒界近傍を詳細任観察すれば, $\mathrm{BeO}$ 添加 $\mathrm{Y}_{2} \mathrm{O}_{3}$ の液相生成に関する情報の得られるととが期待さ れるが, レプリカ法による電子顕微鏡観察結果では, 液 相あるいは異相らしきものを確認できなかった。

また, 本研究では焼結過程で発生する液相量や， $\mathrm{Y}_{2} \mathrm{O}_{3}$ 粒子の液相中への溶解度などについての結果も得ていな いが, $1600^{\circ} \mathrm{C}$ 以上での $\mathrm{Y}_{2} \mathrm{O}_{3}$ のち密化に対し, $\mathrm{BeO}$ の 存在による液相の発生が大きく影響しているすのと推定 される.

なお，添加された $\mathrm{BeO}$ が拝散して $\mathrm{Y}_{2} \mathrm{O}_{3}$ 中の残留量 がきわめて少なくなること结，焼結体中の光散乱を減少 させ，光透過率を增加する上で非常に勃果的であると思 われる。

\section{$\mathrm{V}$ 結 言}

$\mathrm{Y}_{2} \mathrm{O}_{3}$ の透明化焼結に及ばす $\mathrm{BeO}$ 添加の影響につい て検討し，以下の結果を得た.

(1) $\mathrm{Y}_{2} \mathrm{O}_{3}$ に $0.1 \sim 0.5 \mathrm{wt} \% \mathrm{BeO}$ を添加するととにより， $\mathrm{Y}_{2} \mathrm{O}_{3}$ の焼結が著しく促進され, 光透過率の高い焼結 体が得られる.

(2)燒結体の光透過率は，1 10 $\mathrm{t} / \mathrm{cm}^{2}$ の範囲内では成形 压力に依存しない。

(3)2150 $2250^{\circ} \mathrm{C}, 50 \sim 300 \mathrm{~min}$ の烓結により, 光透過率 $80 \%$ (厚さ $1.0 \mathrm{~mm}$, 波長 $300 \sim 7000 \mathrm{~nm}$ ) の焼結体が 得られ，乙れは単結晶 $\mathrm{Y}_{2} \mathrm{O}_{3}$ の值と同等である.

(4) $\mathrm{Y}_{2} \mathrm{O}_{3}$ に添加された $\mathrm{BeO}$ は焼結過程で揮散し, $1800^{\circ} \mathrm{C}$ 以上では添加量の $1 / 2$ 以下となる。このととは焼結体 中の光散乱中心を减少させる上で極めて有効之考えら れる.

(5) $\mathrm{BeO}$ 添加 $\mathrm{Y}_{2} \mathrm{O}_{3}$ 系の高温でのち密化に対し, 液相が 関与していると推測される.

\section{文献}

1) R. C. Anderson: GE Report, NO69-C-141, (1969).

2) R. A. Lefever and J. Matsko: Mat. Res. Bull., 2 (1967), 865.

3）佃：筧協, 85 (1977) 149.

4) W. D. Campbell: J. Illumination Eng., 1 (1972), 281.

5) L. A. Brissette and P. L. Burnett: J. Am. Ceram. Soc., 49 (1966), 165.

6) S. K. Dutta and G. E. Gazza: Mat. Res. Bull., 4 (1969), 791.

7) C. Greskovich and K. N. Woods: GE Report, NO. 72CRD243 (1972).

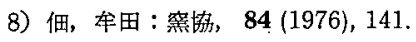

9）企開特許公報, 昭 54-17910 (1979-2).

10）公開特許公報，昭 54-17911 (1979-2). 
11) T. Yamada, etal.: High Temp.-High Pressure, 18 (1986), 3777.

12）山田, 水野, 吉村, 宗宮：案業協会昭和62年度講演予稿集 (1987), 879.

13）特許公報, 昭45-11226.

14) 戸田，野吕，毕田：粉体扰よび粉末冶金，21 (1974), 76.

15）佃，化田：窖協，84 (1976)，585.

16) Г. B. CAMCOHOBA: 酸化物便覽，日・ソ通信社 (1969).

17) Phase diagram for Ceramist, Am. Ceram. Soc., (1964), 100.
18）水野, 山田, 川上, 石井：窯協，93 (1985), 404.

19) W. J. Smothers and H. J. Reynolds: J. Am. Ceram. Soc., 37 (1954), 588.

20）兵野, 黄, 中川, 大矢：窝協, 94 (1986), 505.

21) W. D. Kingery: Kinetics of High-Temperature Processes, John Wiley and Sons, Inc., (1959), 187.

22) F. Kools: Ber. Dt. Keram. Ges., 55 (1978), 301.

23）会元, 谷口, 沼田, 麻生：窒協, 93 (1985), 517.

24）小松, 守吉, 止熊：穼協, 92 (1984), 299.

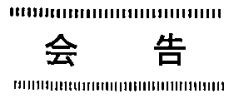

\section{第 5 回セラミック・セミナー}

$$
\begin{gathered}
\text { 一七ラミック材料設計墖一 } \\
\text { ニューセラミックスは超えられる。 }
\end{gathered}
$$

\footnotetext{
主 催：日本セラミックス協会行事企画委員会

協 賛 : 粉体粉末冶金協会他

日 時：昭和63年10月25日(火) 10月28日(金)

会 場: 東京・八王子七ミナー八ウス
}

（八王子市下柏木1987-1ＴEL 0426(76)8511）

申込楴切：定員60名になり次第.

プログラム：

1. エレセラ設計論（日本電気基礎研） 米滓 正智

2. 機能設計論 [総論] (東大) 柳田 博明

3. エンセラ設計論 （防大）新原 皓一

4. エンセラ設計論 （東工大）井関 孝善

5. トピックス

6. ニューガラス設計諭（東工大）川副博司

7. 新材料設計論 (山梨大）木野村暢一

8. インテグレート材料設計論 (阪大) 川合 知二

9. トピックス

10. 超伝導セラミックスの設計論

（長岡技科大）高田 雅介

11. バイオセラミックス設計論

（無機材料）門間 英毅

\begin{tabular}{|c|}
\hline 学生会員 \\
\hline 非会員 \\
\hline
\end{tabular}

参加費：主催・協賛学協会会員 100,000 円，

申込方法：(1)氏名, (2)所属, (3)連絡先, を明記のうえ参 加費を添えて現金書留で下記あてお电し込み 下さい。

申込先 : 160 新宿区百人町 $2-22-17$

日本セラミックス協会行事企画委員会 IER 03(362) 5232

\section{第119回塑性加エシンポジゥム}

『塑性加工過程の数值

1988年 9 月

\section{シミュレーションの現状と問題点』 \\ 一各種シミュレータの現状と态用一}

日 時：昭和64年 2 月 1 日(水) $9: 25 \sim 17: 00$

会 場：建設交流館 603 号室

干550大阪市西区立壳堀2-1-2 Tel 06(543)2551

主 催：日本塑性加工学会（企画：関西支部）

協 賛：粉体粉末治金協会他

プログラム：(各40分） 9:30〜12:10，13:00〜 17:00

○塑性加工過程のシミュレーション法の概論

（神大）富田 佳宏

○鍛造過程のシミュレーション（阪大）小坂田宏造

○圧延過程のシミュレーション

（京工繊大） 森 謙一郎

○板成形過程のシミュレーション

（八代工専(現オハイオ大)）仲町 英治 ○射出成形過程のシミュレーション

（東レ珠）田中豊喜

○静水任成形過程(HIP, CIP) のシミュレーション

(神正製鋼可) 中川 知和

○沉用シミュレータの現状

（日本情報サービス俶）土井平太郎，（武田技術開

発跘）金沢 京子, (日本マーク蚮) 山縣 延樹 総合討論司会】（京大）島進 定 員：100名(定員になり次第締切)

参加費：会員 5,000円

一般 10,000 円（テキスト代を含む）

テキストのみ必要の場合：会員 3,000 円

（但し協賛学協会員は会員扱い）

$$
\text { 一般 } 6,000 \text { 円 }
$$

申込方法：ハガキ大の用紙に「第 119 回塑性加工シンポ ジウム用込み」と題記し，氏名 通信先 勤 務先（部課名・電話番号）を明記の上，代金 を添えて現金書留でお申込み下さい。

後日，参加券・交通案内図を抢送り致します。

申込先：干657 神戸市灘区六甲台町

神戸大学工学部機械工。学科内

日本塑性加工学会関西支部

TEL078(881)1212 内線5136，5133，5126 